GLOBAL JOURNAL OF SOCIAL SCIENCES VOL 11, NO. 2, 2012: 107-117

COPYRIGHT@ BACHUDO SCIENCE CO. LTD PRINTED IN NIGERIA. ISSN 1596-6216

\title{
A CRITICAL EVALUATION OF THE OGUI SLUM IN ENUGU, NIGERIA
}

\author{
C. C. NWACHI, E. A. AGBOR AND S. A. INAH
}

(Received 26 May, 2011: Revision accepted 4, June 2012)

\begin{abstract}
The high rental value of core city areas has always influenced the formation of slums at the peripheries or outskirts of towns and cities of the developing world. However, a peculiar inner-city slum that has persisted over the years is the Ogui slum in Enugu, Nigeria. This paper tried to identify the factors that has made this inner-city slum to persist. One factor that has acted as a boost for others to thrive is the indigenous dwellers' hold on land. The other factors include the centrality of the slum in the town and its close proximity to various schools, markets and places of work. However, the unprecedented influx of people into Enugu in the early 1970's overstretched the existing facilities in the city and turned the indigenous land of Ogui into a slum. The paper went on to give recommendations on how to effect renewal schemes for the study area. Critical to this effort is the employment of public participation in the process as being emphasized by the Urban Management Programmes (UMP) of the UN - Habitat projects. More critical to the renewal effort will be the prompt payment of adequate compensation to indigenes for lands acquired for the programme.
\end{abstract}

KEYWORDS: Inner-City Squatting, Peri-Urban Squatting, Slum

\section{INTRODUCTION}

The formation of squatters and slums in the cities of the developing world has been on the increase. Evidently, explosive urbanization and population increases have their manifestation in high density of persons within limited space which arose due to rural-urban migration, over concentration of socio-economic activities and non-compliance with planning guidelines (Sule,2001). The squatter and slum led to massive urban sprawls in the peripheries due to the fact that the new migrants cannot afford the rent of the central areas. For instance in Bangkok, unplanned and uncoordinated development in the metropolis of 9 million people (14 percent of the country's population) is characterized by massive urban sprawl radiating up to 50 kilometres in all directions (Stickland, 1993).

In retrospect, a regional workshop sponsored by several United Nations' agencies in 1975 emphasized that the ominous background in the developing countries was the extremely explosive urban growth which has resulted in the development of numerous marginal settlements in which people live in an environment of squalor, lacking essential services to provide for basic human needs. (Ekistics Documentation 1975). Most urban analysts emphasize the spread and development of fringe squatters as being peculiar to the developing countries and inner-urban squatters as being peculiar to developed societies. An example of inner-urban squatting settlement in a developed society is the London case as studied by Elkin (1974). Elkin opined that

C. C. Nwachi, Department of Urban and Regional Planning, Cross River University of Technology, Calabar, Cross River State, Nigeria.

E. A. Agbor, Department of Urban and Regional Planning, Cross River University of Technology, Calabar, Cross River State, Nigeria.

S. A. Inah, Department of Urban and Regional Planning, Cross River University of Technology, Calabar, Cross River State, Nigeria. 
peri-urban squatting is traditionally practiced by third world squatters.

However, this research tried to isolate a particular case study of inner-urban squatting in a developing economy. This is found in the coal city, Enugu, the capital city of Enugu State, Nigeria. The nature and form of these squatting in Ogui and its environs has elicited interest in urban researchers due to its persistency despite several governmental efforts for its renewal. This study arose out of the need to draw attention to core city in a developing economy. It is being suggested that there would be poor connectivity cohesiveness between landuse activities in the city since the center is acting as a disruption especially for transportation. No meaningful transportation network for the city can be effective without thoroughfares passing through the core area of the city. This paper therefore has attempted to examine the causes and reasons for the rise and emergence of this slum. It also went further to evaluate the effects of this settlement on its environs and Enugu City as a whole.

\section{Historical Overview of Enugu City}

Enugu is the capital of Enugu State, Nigeria. The city was originally called 'Enugu Ngwo" before it was changed to Enugu. It is surrounded by hills which led to its name meaning "Top of the Hill" in Igbo language. The first settlement in the town was the small Nike village of Ogui. After the discovery of coal in
1909, Enugu became a major coal mine with Udi mine and Iva valley mine being the first mines.

With the mines, a railway connecting Enugu with Port Harcourt sea port was completed in 1916 - making way for direct contact with Europeans. Enugu became the administrative capital of the Eastern province in 1938. In 1967, when Nigeria was divided into 12 States, the Eastern region was broken up and Enugu was made the capital of east Central State.

Following the national crisis of 1967, it was declared capital of the short-lived Republic of Biafra. It again became the capital of East Central State after the war in 1970. On February 3, 1976, the East central State was broken into two new States of Imo and Anambra with Enugu as the capital of Anambra. In 1991, when the old Anambra State was divided into two new states of Enugu \& Anambra, Enugu still remained the capital of Enugu State.

The largest indigenous people of Enugu are the Ogui Nike who live in the areas surrounding Hotel Presidential, Obiagu, AmaIgbo, Ihewuzi and Onu-Asata (The Free Encyclopedia,2009). The Achara layout and Uwani areas are inhabited mainly by the Awkunanaw people. The Enugu Ngwo people live on hilltops with their farms in the valleys. With time, these various indigenous groups grew to form a city. Other areas of Enugu include Abakpa, lji-Nike, coal camp and Emene. 
The northern section of Enugu city with the location of Ogui slum is shown on Figure 1.

Figure 1.

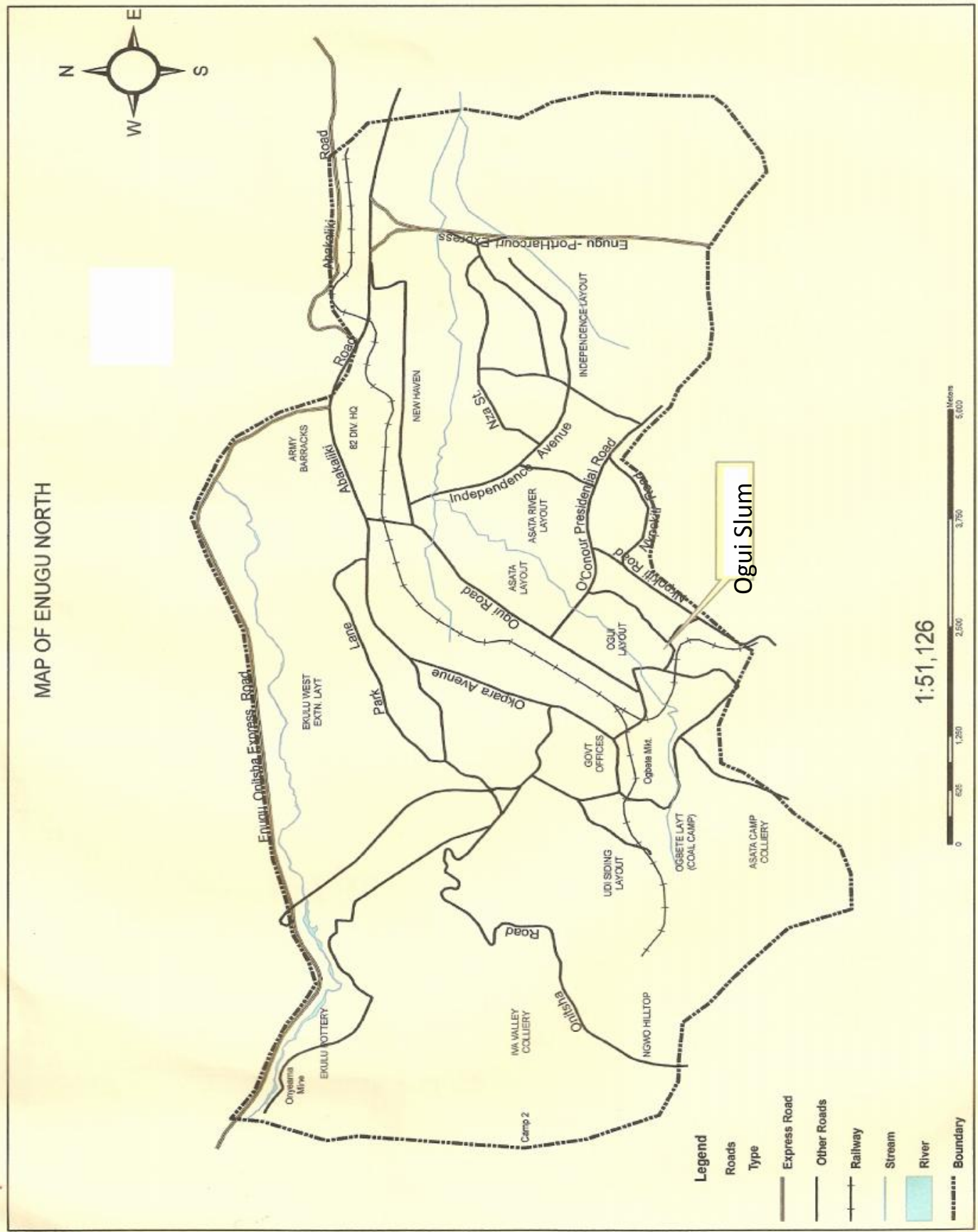

Researcher's Filed Work 2009 
PREVIOUS RESEARCH

The United Nations Agency UNHABITAT defines a slum as a heavily populated urban area characterized by substandard housing and squalor. These areas usually house the very poor or socially disadvantaged groups of the society. An assessment by the UN-HABITAT also show that the world slums are concentrated in Africa and central America. Urban slum report on Ibadan (Mabogunje, 1962) show that slums are prominently found on the outskirts.

In support, Abumere (1985) stated that about $62.5 \%$ of Slums in Nigerian cities were found within a radius of $1 \mathrm{~km}$ from the city centre. However if there are no resources for urban renewal, the city centre, which is the oldest by definition turns into a slum in time as depicted by Ogui slum in Enugu. Nonetheless, the persistency may not be entirely due to lack of resources but also a combination of other variables.

In fairly large cities such as Lagos, Ibadan, Kano \& Enugu, a considerable portion of slums occur at the city outskirts, more than $5 \mathrm{~km}$ from the centre (Abumere, 1987).

In most cases, slums in the developing world are attributed to the astronomical growth in the urban population. When the provision of urban facilities and infrastructures cannot meet up with this rising population trend, deterioration of the urban environment sets in. Several scholars have examined this trend of urban population growth and deterioration of the environment. Such authors include Abiodun (1982), Eni (2005), Sule (2004), Baum \& Valins (1973) and Sethuranman \& Ahmed (1992). According to Eaves (2009), an estimated 5 billion of the world's 8.1 billion people will live in cities by 2030 . About 2 billion of them will live in slums, primarily in Africa and Asia, lacking access to clean drinking water and working toilets, surrounded by desperation and crime. Davis (2006) in examining Nigeria's urban population emphasized that nearly $80 \%$ of the country's urban population or some 41.6 million people live in slums. The comparable numbers in India are $56 \%$ and 158.4 million respectively.

In most cities of the developing world, the high rental value of city centres makes it unaffordable for the urban poor thereby pushing their squatting settlements to the fringes or outskirts of the cities. In the developed world, the process of urban decay in the city centres encourage squatting for the urban poor.

In the case of Enugu city, the Ogui squatting settlement is right at the heart of the city. The slum is located at the homesteads of the largest group of indigenous people of Ogui Nike. The squatting settlement extends from Obiagu, Ama-Awusa, Onu-Asata to Ogui road axis. This squatting settlement or slum kept on developing both in size and population from preindependence days till date as shown on Plates 1 and 2. 
Plate 1: Part of Ogui Slum in Enugu.

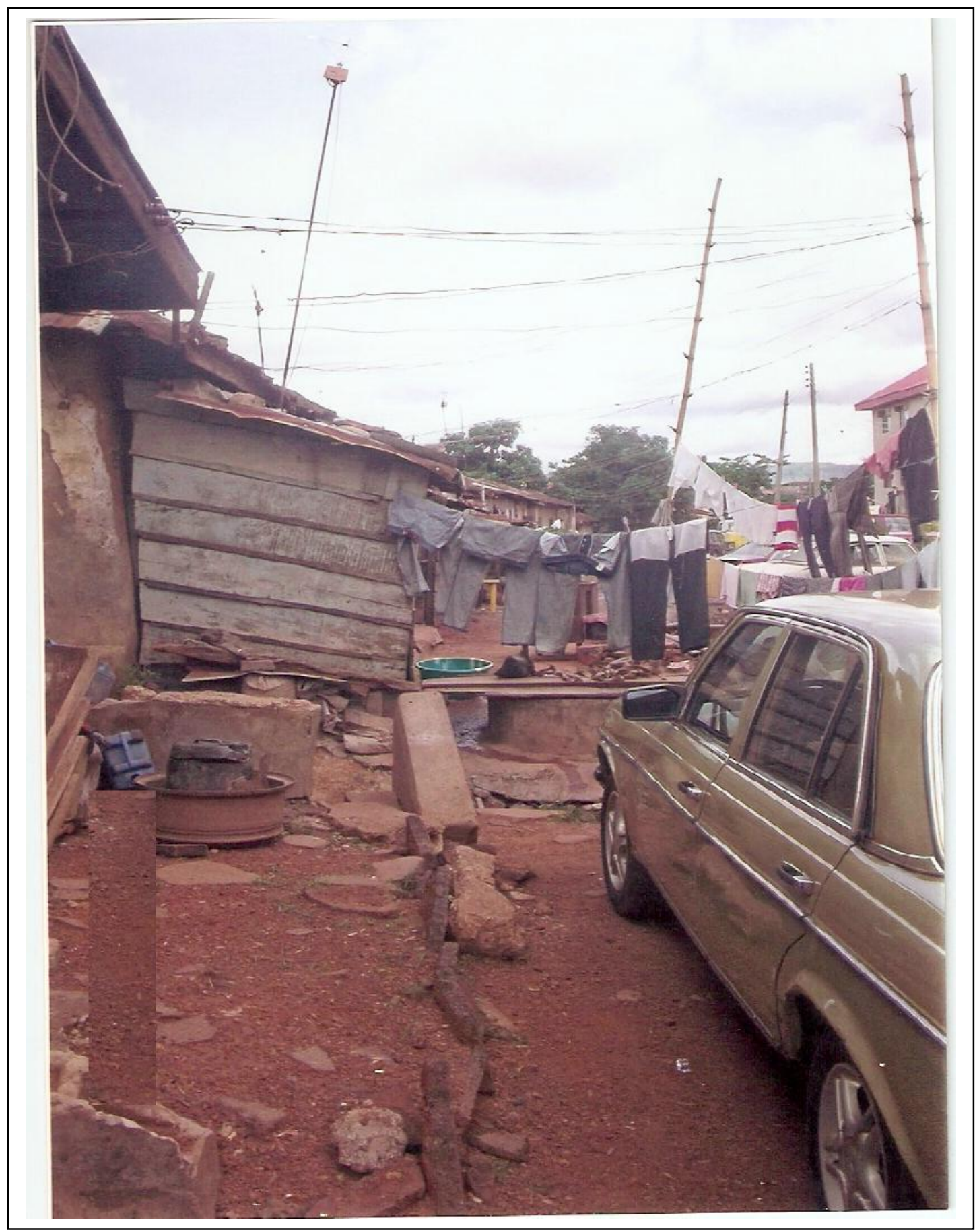

Researcher's Filed Work 2009 
Plate 2: Part of Ogui Slum in Enugu.

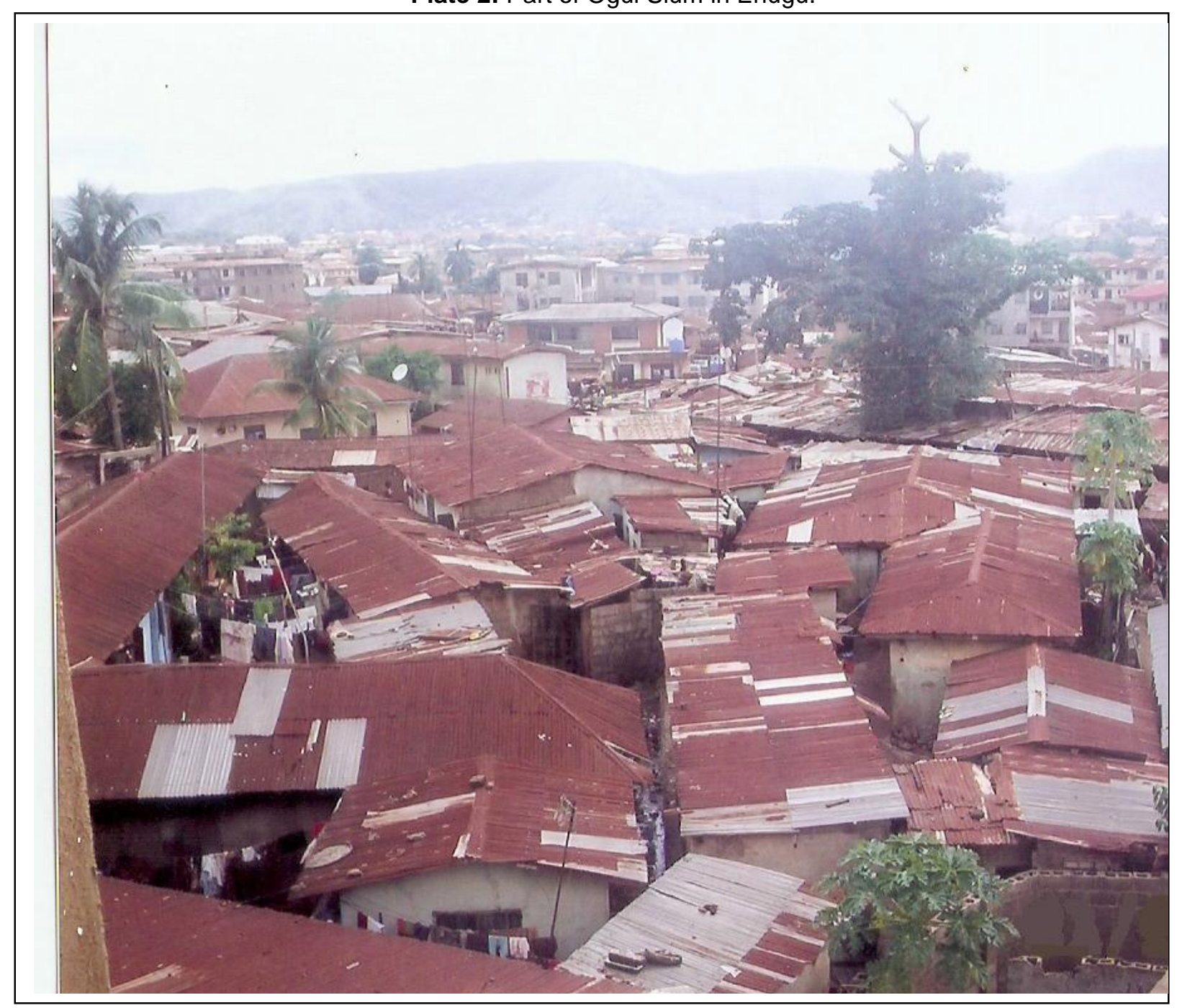

Researcher's Filed Work 2009 
The broad objectives of this research therefore are outlined as follows:

To establish the slum characteristics of Ogui slum

To identify the major variables that contributed to the growth and persistency of this slum.

\section{Method of Study}

To achieve the objectives of this study, both the primary and secondary data were utilized. For the primary data, the Participatory Appraisal (PA) method was employed in the field survey. The techniques in this method include direct observation, checklist (Semi-structured interview) and questionnaires. On the other hand, the secondary data include the use of maps in showing the central position of Ogui Slum in Enugu city and photographs depicting the existing environmental situation of the study area. Qualitative and descriptive statistics such as pie chart, percentages and tables were used to analyze the data.

\section{Result and Discussions}

The general living conditions in Ogui slum, Enugu are depicted on the following table.

Table 1: Survey Summary of Housing Characteristics in Ogui Slum in Enugu City.

\begin{tabular}{|c|c|c|}
\hline Housing Characteristics & $\begin{array}{l}\text { Frequency } \\
N=500\end{array}$ & $\%$ \\
\hline \multicolumn{3}{|l|}{ Type of dwelling } \\
\hline Rooming type & 418 & 83.6 \\
\hline Self-contained bungalow & 62 & 12.4 \\
\hline Self-contained flats (story building) & 08 & 1.6 \\
\hline \multirow[t]{2}{*}{ Duplex others } & 07 & 1.4 \\
\hline & 03 & 0.6 \\
\hline \multicolumn{3}{|l|}{ Dwelling facilities } \\
\hline $\begin{array}{l}\text { Toilet } \\
\text { None }\end{array}$ & 67 & 13.4 \\
\hline Pit latrine & 314 & 62.8 \\
\hline Bucket system & 32 & 6.4 \\
\hline WC system & 87 & 17.4 \\
\hline Bathing facility & 22 & 4.4 \\
\hline Open enclosure & 447 & 89.4 \\
\hline Shared bathroom & 22 & 4.4 \\
\hline Standard bathing facilities & 09 & 1.8 \\
\hline \multicolumn{3}{|l|}{ Kitchen } \\
\hline Common kitchen & 168 & 33.6 \\
\hline Private kitchen & 27 & 5.4 \\
\hline \multicolumn{3}{|l|}{ Direct access to dwelling } \\
\hline None & 100 & 0.2 \\
\hline Path & 305 & 61 \\
\hline Track road & 64 & 12.8 \\
\hline Untarred road & 17 & 3.4 \\
\hline Tarred road & 14 & 2.8 \\
\hline \multicolumn{3}{|l|}{ Housing Type } \\
\hline Mud type & 53 & 10.6 \\
\hline Cement/mud type & 297 & 59.4 \\
\hline Cement & 150 & 30.0 \\
\hline \multicolumn{3}{|l|}{ Roofing Type } \\
\hline Raffia & & \\
\hline
\end{tabular}




\begin{tabular}{|l|l|l|}
\hline Zinc & \multicolumn{2}{|l|}{ Not administered } \\
\hline Asbestos & & \\
\hline Services Available & & \\
\hline $1 . \quad$ Electricity & & 77.8 \\
\hline$\quad$ Available & 389 & 22.2 \\
\hline$\quad$ Not available & 111 & \\
\hline $2 . \quad$ Pipe-borne water & & 5.6 \\
\hline$\quad$ Available & 28 & 94.4 \\
\hline$\quad$ Not available & 472 & \\
\hline $3 . \quad$ Refuse evacuation & & 2.2 \\
\hline$\quad$ Available & 11 & 97.8 \\
\hline$\quad$ Not available & 489 & \\
\hline $4 . \quad$ Drainages & & 7.8 \\
\hline$\quad$ Available & 39 & 92.2 \\
\hline$\quad$ Not available & 461 & \\
\hline
\end{tabular}

Source: Researchers' field survey, 2009

From the table, it is clear that the living conditions in Ogui slums are substandard, unhealthy and deplorable. There are traditional slums arising in towns from the decay of existing structures and there are spontaneous slums created by squatters on illegally acquired lands (Agbola 1987). Ogui slum could be regarded as a traditional slum. Mabogunje (1962) intimated that with the development of towns, the core area 'growth by fission', compounds were broken up into a number of separate housing units. In evaluating the housing quality, a greater percentage of the houses used in the survey lack basic amenities. Having established that Ogui ghetto has developed into a slum, this paper tried to identify the cause(s) of this slum and its persistency. Responses elicited from the slum dwellers are shown on table 2 and represented on the attendant pie chart.

Table 2: Factors influencing slum dwelling at Ogun

\begin{tabular}{|l|l|l|}
\hline Factor & $\begin{array}{l}\text { Frequency of responses } \\
\mathbf{N = 7 0 0}\end{array}$ & $\%$ \\
\hline Finance: & 580 & 82.9 \\
Income & & \\
Slum location (centrality:) & 531 & 75.9 \\
Nearness to workplace & 402 & 57.4 \\
Nearness to market & 565 & 80.7 \\
Nearness to schools & & \\
Others: & 280 & 40.0 \\
Family compound & 113 & 16.1 \\
Personal reasons & & \\
\hline
\end{tabular}

Source: Researchers' Field survey 2009. 


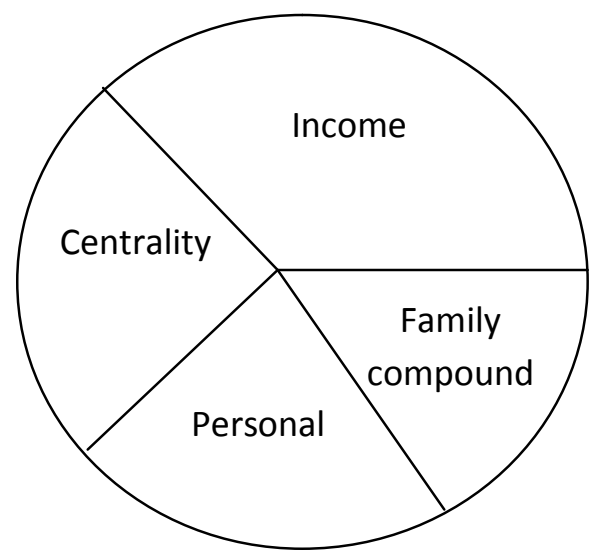

Figure 2: Pie chart showing dominant factors influencing slum dwelling in Ogui, Enugu.

From table 2 and pie chart shown, it is quite clear that income and centrality variables are the leading factors influencing the persistency of Ogui slum. With the high price of urban land combined with the high cost of housing, the lowincome groups in Enugu central area are left few choices but to remain in the slum. An insight into the cost of housing is given on table 3 .

Table 3: Mean Annual Rental trend for tenement building and 3 bedroom flats in Enugu Urban.

\begin{tabular}{|c|c|c|}
\hline Year & Tenement(per room) p.q & 3 bedroom flat p.q \\
\cline { 2 - 3 } 1997 & $N$ & $N$ \\
1998 & 6,000 & 15,000 \\
1999 & 7,200 & 15,000 \\
2000 & 9,600 & 21,600 \\
2001 & 10,800 & 24,000 \\
2002 & 12,000 & 30,000 \\
2003 & 12,000 & 96,000 \\
2004 & 14,400 & 96,000 \\
2005 & 18,000 & 120,000 \\
2006 & 21,000 & 120,000 \\
2007 & 24,000 & 180,000 \\
2008 & 36,000 & 180,000 \\
& 36,000 & 240,000 \\
& & \\
\hline
\end{tabular}

Source: Egbenta R.I. (2009) Field Survey Report.

In a country, where the low-income constitutes a greater percentage of the population, and living with barely one dollar a day, saving such an amount of money for house rent becomes a herculean task. In addition, it is observed that there seemed to be unprecedented and sudden influx of people form one parts of Eastern region into Enugu immediately after the Nigerian Civil War of 1967- 1970. This is as shown on Table 4. 
Table 4: Period of Migration into Ogui (Indigenous Landlords only)

\begin{tabular}{|l|l|l|l|l|l|l|}
\hline $\begin{array}{l}\text { Period of } \\
\text { invasion of } \\
\text { Oguui by } \\
\text { non- } \\
\text { indigenes }\end{array}$ & Period & $1960-1965$ & $1965-1970$ & $1970-1975$ & $1975-1980$ & $1980-1985$ \\
\hline Response & & 07 & 09 & 79 & 04 & \\
\hline
\end{tabular}

Source: Researchers' Field work, 2009.

From the oral interview with the indigenous landlords, there have been attempts even in the post civil war days by the East central State government to embark on renewal schemes for Ogui area. This was resisted because of the Indigenous people's hold on their ancestral lands.

\section{RECOMMENDATIONS AND CONCLUSION}

There is a great challenge to the government, for all its agencies and nongovernmental organizations responsible to work out pragmatic schemes of revitalizing the Enugu central area - Ogui slum. Such measures should include

- Proper co-ordination, orientation and public awareness of the government's efforts through public meetings and through the media.

Effective modalities as to how, and when to pay adequate compensations for acquiring indigenous lands.

Effective relocation schemes for Ogui dwellers to satellite towns so as to carry out the renewal activities effectively.

In conclusion, it is important to state here that for several decades, the Ogui slum seem to defy solutions. Its persistency seems to be indelible and synonymous with Enugu town. The underlying factor of this persistency lies in the fact that urban rehabilitation and renewal could not keep up with the rate of urban growth. As observed by Giok and Kai(2007), the formation of slum need not be inevitable with rapid urbanization. They emphasized that city authorities faced with rapid development lack capacity to cope with the diverse demands for infrastructural provisions to meet economic and social needs. No effective Housing Scheme was put in place in Eastern Nigerian cities to meet the demands of displaced persons immediately after the civil war. If such were available Ogui Nike would not have degenerated into a slum.
In retrospect, Aprinka (2009) observed that slums and squatter settlements are the result of people being priced out of legal housing markets. The present housing situation in Ogui and its environs is a pointer to the fact that the government and other responsible agencies lack adequate data on housing needs in Nigerian urban centers.

\section{REFERENCES}

Abiodun, J. O., 1982. The Provision of Housing and Urban Environmental Problems in Nigeria. Abiodun J. O. ed. (1982). Urban \& Regional Planning Problems in Nigeria. University of Ife Press Ltd. 187.

Abumere, S. I., 1985. The Nigerian Urban Environment and the Problem of Slums. Unpublished Paper, Department of Geography, University of Ibadan.

Abumere, S. I., 1987, Urbanization and Urban Decay in Nigeria. In P. Onibokun et. A. (Eds) Urban Renewal in Nigeria, NISER.

Agbola, T., 1987. Urban Renewal: A Case Study of Lagos Metropolitan Area. In P. Orubokun et. Al (Eds) Urban Renewal in Nigeria, NISER

Aprinka, I. M., 2009. Millennium Development Goals and Slum Eradication. The case of Port Harcourt, Rivers state Journal of the Nigerian Institute of Town Planners(NITP), October, 2009, 49-52.

Baum, A and Valins, S., 1973. Residential Environments: Group, Size and Crowding Proceedings of the American Psychology Association. 211 - 212.

Davis, M., 2006. Plannet of Slums, London, Nye York. ISBN 1-84467-022-8 
Eaves, E., 2007. Two Billion Slum Dwellers, PMET,http://www.forbes.com/2007/06/11 third world slums.

Egbenta, R. I., 2009. Analysis of Residential Land use change in Enugu Urban, Journal of Environmental Management and Safety (IEMS) www.cepajournal.com Retrieved April 2012

Ekistics Documentation., 1975.

Elkin, S. L., 1974. Politics and Landuse planning: The London experience, Cambridge University Press, 78-79.

Eni, D. D., 2005. Philosophy and Methodology of Environmental Science, Ultimate Index Publishers, Calabar, Nigeria. 101-103.

Falade, J. B., 2005. Needs and opportunities for meeting challenges of Urban Development in West African Region. Paper presented at the Agenda Setting Workshop=CAP 2006 World Planner Congress. Nov.2005, Abuja

Giok, L. O and Kai, H. P., 2007. Urbanization and Slum Formation, The New York Academy of Science 2007, published online 2007 March 27, doi: 10.1007/S11524-007-9167-5

Mabogunje, A. L., 1962. The Growth of Residential Districts in Ibadan, Geographerical Review 1,

Nnah, W. W., 2006. Development Control in Rivers State: What prospects in the New Millennium? Paper presented at the NITP stakeholders' confidence for Developers, Port Harcourt 2006.

Sethusanman, S. V and Ahmed, A., 1992. Urbanisation, Employment and the Environment. In Bhalia A. S. (1992). Environment, Employment and Development. International Labour Office, Switzerland.

Stickland, R., 1993. Bangkok's Urban Transport Crisis, The Urban Age: Urban Transport Issues. 2, (1): 1993.
Sule, O. R., 2001. Urban Environmental Pollution Criticality: A synopsis. BAAJ, Calabar.

Sule, O. R., 2004. The Environmental Consequences of Rapid Urbanization in Countries of the Developing World. Thumbprints Inter. Coy., Calabar, pp.13.

The Free Encyclopedia., 2009. 